\title{
Effect of Nicotinic Acid on Abnormal Serum Lipids*
}

\author{
O. FITZGERALD, M.D., M.SC.; A. HEFFERNAN, † M.D.; P. BRENNAN, M.D.; R. MULCAHY, M.D., M.R.C.P. \\ J. J. FENNELLY, $\ddagger$ M.B., B.CH.; R. McFARLANE,§ M.I.S.T.
}

Brit. med. F., 1964, 1, 157-159

In 1955 Altschul and his associates reported on the cholesterollowering effect of nicotinic acid administered to normal subjects. This has been confirmed and extended to include hypercholesterolaemic subjects, on whom a similar effect was demonstrated (Parsons et al., 1956 ; O'Reilly et al., 1957 ; Comesaña et al., 1958 ; Achor et al., 1958 ; Galbraith et al., 1959). The purpose of this paper is to report our experience of the effect of nicotinic acid (N.A.) on total lipids, serum cholesterol, and beta-lipoprotein in patients with clinical evidence of atherosclerosis or hypercholesterolaemia. Also we record its effect on lipid tolerance, of which there is one other account in the literature (Berkowitz et al., 1962), and on heparin clearing of lipaemic plasma. A preliminary account of this work has been reported elsewhere (FitzGerald et al., 1960).

\section{Material and Methods}

Persons were selected for treatment when the fasting level of total lipids and/or cholesterol in their serum exceeded 530 and $230 \mathrm{mg} . / 100 \mathrm{ml}$. respectively and when circumstances of residence or travel permitted visits at regular intervals. None of the group studied had hypothyroidism, nephrosis, or diabetes mellitus. All were followed up as out-patients. Detailed histories were taken and complete physical examinations and appropriate laboratory tests were performed prior to and at intervals during the study. The tests included routine urinalysis, determination of blood urea, chest $x$-ray examination, and E.C.G. Careful notes were made of symptoms and signs of coronary, peripheral, and cerebrovascular insufficiency, of the size of xanthelasmata or tendinous xanthomata, and of side-effects. Liver-function tests and uric-acid estimations were carried out on a limited number of subjects.

Each subject was started on N.A. as an in-patient and the dosage was increased over one week from $0.3 \mathrm{~g}$. daily on the first day to $3 \mathrm{~g}$. daily on the 7 th to 10 th days. $3 \mathrm{~g}$. daily was the accepted initial therapeutic dose. The drug was finally administered after the initial period in the form of a tablet containing 0.5 g., and it was taken in three divided doses with meals. The dose of N.A. was increased above $3 \mathrm{~g}$. daily in a limited number of patients after a period of study.

Each patient was advised to continue the diet and treatment regimen used prior to starting N.A. therapy. All patients had fasting total lipid, serum cholesterol, and lipoprotein estimations. In addition 28 of them had a full lipid-tolerance test and a measurement of the heparin-induced clearing of lipaemic plasma. Throughout the period of treatment with N.A. fasting blood lipids were studied at frequent intervals. In certain subjects the lipid-tolerance test and heparin-clearing were also measured regularly. The clinical and chemical details of the methods employed have been dealt with elsewhere (FitzGerald et al., 1963). Lipoprotein patterns were obtained by paper electrophoresis according to the method of McFarlane (1962).

\footnotetext{
- From St. Vincent's Hospital and Department of Medicine and Therapeutics, University College, Dublin.

$\dagger$ Now at the Middlesex Hospital, London.

$\ddagger$ Now at the Sloan-Kettering Institute, New York, U.S.A.

$\S$ Technical assistant.
}

\section{Case Material}

Between May 1959 and November 196140 patients (32 men and 8 women) received N.A. for varying periods. The age and sex distribution is shown in Table I. The mean age of the patients treated was 49.9 years, the range being 10 to 64 years. Coronary heart disease was present in $35(88 \%)$ subjects and in three of these peripheral vascular disease was also present. The other $5(12 \%)$ cases had arterial disease elsewhere. Table II gives the distribution of patients according to duration of treatment.

\begin{tabular}{c|c|c|c|c}
\multicolumn{5}{c}{ Table I. - Age and Sex Distribution } \\
\hline Age & Male & Female & Total & $\%$ \\
\hline $10-19$ & 1 & - & $\frac{1}{4}$ & $\frac{2 \cdot 5}{10}$ \\
$20-29$ & $\frac{1}{3}$ & 3 & 12 & 30 \\
$30-39$ & 9 & 17 & $42 \cdot 5$ \\
$40-49$ & 16 & 3 & 6 & 15 \\
\hline $50-59$ & 3 & 89 & 40 & 100 \\
\hline
\end{tabular}

The differences in the duration of treatment are accounted for by a number of factors such as late entry to the study, defaulting, discontinuing treatment because of side-effects, and ending of treatment because of death or because of satisfactory or unsatisfactory clinical biochemical response.

\section{Results}

Before the end of November 196140 persons had begun the programme of study and 21 had participated for at least one year (Table II).

TABLB II.-Duration of Treatment of 40 Cases

\begin{tabular}{rr|c|c|c|c|c|c|c|c|c|c|c}
\hline \multicolumn{2}{r|}{ Months. } & $0-$ & $3-$ & $6-$ & $9-$ & $12-$ & $15-$ & $18-$ & $21-$ & 24 & $27-$ & 30 \\
\hline $\begin{array}{ll}\text { No. } \\
\%\end{array}$ & $\ldots$ & 7 & 4 & 4 & 4 & 3 & 5 & 4 & 3 & 1 & 3 & 6 \\
\hline
\end{tabular}

\section{Total Lipids and Cholesterol}

The mean changes in the total lipids and total cholesterd concentrations in the 21 persons treated for at least one year cre presented in Table III. The mean decrease in total lipids was

TABLE III.-Blood Lipid Changes in 21 Patients Treated with NiconiniAcid for One Year

\begin{tabular}{|c|c|c|c|c|c|c|c|}
\hline \multirow[b]{2}{*}{ Period } & \multirow{2}{*}{ 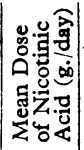 } & \multicolumn{3}{|c|}{ Total Lipids } & \multicolumn{3}{|c|}{ Total Chalesterol } \\
\hline & & $\begin{array}{c}\text { mg. } / 100 \mathrm{ml} . \\
\text { (Mean } \\
\text { and S.E.) }\end{array}$ & $\mathrm{P}^{*}$ & $\underset{(\%)}{\text { Change }}$ & $\begin{array}{c}\text { mg. } / 100 \mathrm{ml} . \\
\text { (Mean } \\
\text { and S.E.) }\end{array}$ & $\mathbf{P}^{*}$ & $\underset{(\%)}{\text { Change }}$ \\
\hline $\begin{array}{l}\text { Pretreat- } \\
\text { ment } \\
\text { Post-treat } \\
\text { ment }\end{array}$ & 3.7 & $\begin{array}{l}847 \pm 66 \cdot 83 \\
599 \pm 33 \cdot 15\end{array}$ & $\begin{array}{c}\cdots \\
<0.001\end{array}$ & $\begin{array}{r}0 \\
-34\end{array}$ & $\begin{array}{l}313 \pm 17 \cdot 69 \\
245 \pm 11 \cdot 27\end{array}$ & $<0.001$ & $\begin{array}{r}0 \\
-25 \cdot 2\end{array}$ \\
\hline
\end{tabular}

* Value of less than 0.05 indicates significant change from value in proceding perioci. 
highly significant, but somewhat less than the mean decrease of total lipids.

Nineteen of the 21 patients treated with N.A. for a year had a total lipid of $530 \mathrm{mg} . / 100 \mathrm{ml}$. or higher before the trial began. Of these 19,9 had a total lipid of $530 \mathrm{mg} . / 100 \mathrm{ml}$. or lower after 12 months of N.A. Of the 21 subjects 3 had a total lipid greater than their pretreatment level at the end of the 12-months period.

In the case of the total cholesterol, 20 patients had a concentration of $230 \mathrm{mg} . / 100 \mathrm{ml}$. or more before treatment and 7 showed a total cholesterol concentration of $230 \mathrm{mg} . / 100 \mathrm{ml}$. or less after 12 months of receiving N.A. Two subjects from this group had cholesterol concentrations above the pretreatment value at the end of the 12 months.

Table IV shows the mean changes in the total lipids and serum cholesterol concentration of six persons treated for at least 24 months. These patients were also included in the group studied for at least 12 months, which has already been discussed. The mean decrease in the total lipids and cholesterol during the frst 12 months was highly significant. The mean decrease in the total lipids for the second 12 months was again significant, but there was virtually no further change in the cholesterol during this period. The mean dose of N.A. remained unchanged during the second 12-months period.

Table IV.-Blood Lipid Changes in Six Patients Treated with Nicotinic Acid for Two Years

\begin{tabular}{|c|c|c|c|c|c|c|c|}
\hline \multirow[b]{2}{*}{ Period } & \multirow{2}{*}{ 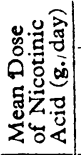 } & \multicolumn{3}{|c|}{ Total Lipids } & \multicolumn{3}{|c|}{ Total Cholesterol } \\
\hline & & $\begin{array}{l}\text { mg. } / 100 \mathrm{ml} . \\
\text { (Mean } \\
\text { and S.E.) }\end{array}$ & $\mathrm{P} *$ & $\underset{(\%)}{\text { Change }}$ & $\begin{array}{c}\text { mg. } / 100 \mathrm{ml} . \\
(\text { Mean } \\
\text { and S.E. })\end{array}$ & $P^{*}$ & $\begin{array}{c}\text { Change } \\
(\%)\end{array}$ \\
\hline $\begin{array}{l}\text { Pretreat- } \\
\text { ment } \\
0-12 \\
\text { months } \\
12-24 \\
\text { months }\end{array}$ & $\begin{array}{l}4 \\
4\end{array}$ & $\begin{array}{l}668 \pm 86 \cdot 88 \\
592 \pm 77 \cdot 10 \\
548 \pm 35 \cdot 52\end{array}$ & $\begin{array}{l}<0.001 \\
<0.01\end{array}$ & $\begin{array}{c}0 \\
-13.9 \\
-20 \cdot 3\end{array}$ & $\begin{array}{l}328 \pm 26 \cdot 69 \\
255 \pm 10 \cdot 53 \\
254 \pm 11 \cdot 18\end{array}$ & $\begin{array}{l}<0.001 \\
<0.8\end{array}$ & $\begin{array}{c}0 \\
-21.9 \\
-22.5\end{array}$ \\
\hline
\end{tabular}

- Value of less than 0.05 indicates significant change from value in preceding period.

The response of the lipids and cholesterol to N.A. therapy during the initial three months of treatment of 33 persons was assessed with respect to pretreatment level of cholesterol and with reference to age and sex.

The decrease in cholesterol in the group of 15 persons whose pretreatment level exceeded the mean of $303 \mathrm{mg} . / 100 \mathrm{ml}$. was significantly greater than that in the group of 18 persons whose level was lower than this mean (Table V). This bears out the findings of Parsons and Flinn (1959) that persons with lower initial levels of cholesterol are less responsive to treatment.

The decrease of total lipids in the group was not significantly correlated with the pretreatment level of lipids or serum cholesterol.

No significant variations of response could be found in any age-group or in either sex when the influence of initially higher figures for cholesterol were taken into account. However, a greater although non-significant decrease in lipids and cholesterol among our female patients supports the findings of Berge et al. (1961), who reported better response in women than in men.

\section{Lipid Tolerance and Heparin Clearing}

The effect on the fasting, the two-hour, and the four-hour optical density, and on the two-hour and four-hour lipid rise was assessed in 18 patients who received a mean dose of N.A. of $3 \mathrm{~g}$./day for three months. At the end of three months there was no statistically significant change in any of these, though all figures showed a mean decrease from the mean pretreatment level. This work confirms the similar recent report of Berkowitz et al. (1962).

N.A. did not have a statistically significant effect on the heparin-clearing mechanism. This was assessed in 17 subjects who received a mean dose of $3 \mathrm{~g}$./day for three months.

The lipoprotein pattern was examined in 23 subjects while they were on treatment. Five persons from this group who had a mean decrease in cholesterol of $40 \%$ from the mean pretreatment level of $305 \mathrm{mg} . / 100 \mathrm{ml}$. also had striking changes in the lipoprotein pattern. Before treatment all five persons had an increased beta-lipoprotein. When the cholesterol decreased on N.A. therapy beta-lipoprotein also decreased, while alphalipoprotein increased. This change in the lipoprotein pattern is presumed to be due to a reversal of the cholesterol content of the lipoprotein bands. These results conform with those of Achor et al. (1958).

However, there were persons in this group of 23 patients whose lipoprotein pattern showed little or no change, although they had a marked decrease in serum cholesterol. In the subjects whose cholesterol responded very slightly, or not at all, to N.A. therapy, the lipoprotein pattern remained unchanged or even disimproved.

\section{Clinical Course of Patients Treated with N.A.}

The relatively small number of cases involved in the trial and its short duration in relation to such a chronic process as atherosclerosis preclude a useful assessment of the clinical progress of the 40 subjects involved. One patient with coronary heart disease showed clearing of xanthelasma patches. Three other patients with xanthelasma palpebrarum showed no change in skin lesions. Another patient suffered from disabling peripheral vasospasm. The vasospasm improved considerably on treatment, and xanthelasmic patches which were present showed nearly complete resolution.

\section{Side-effects}

Cutaneous flushing was noted to some extent by all persons initially. A chronic history of flushing of mild degree, especially if the patient failed to take the N.A. with food, could be obtained from $23 \%$ of patients after the initial period of treatment, but was not an objectionable side-effect. Also in $23 \%$ a skin rash was noted, while another $8 \%$ developed a dry scaly skin. Two patients on N.A. had treatment discontinued because of furunculosis. Pruritus was noted in $5 \%$ of cases, but it never became intolerable.

Gastro-intestinal irritation, with nausea, flatulence, sensations of fullness, diarrhoea, heartburn, and epigastric pain, was

TABle V.-Effect of Nicotinic Acid on Total Lipids and Serum Cholesterol (Response during First Three Months of Treatment in 33 Patients)

\begin{tabular}{|c|c|c|c|c|c|c|c|c|c|c|c|}
\hline \multirow[b]{2}{*}{$\begin{array}{l}\text { Pretreatment } \\
\text { Cholesterol }\end{array}$} & \multicolumn{2}{|c|}{ Patients } & \multicolumn{3}{|c|}{ Total Lipids (mg./100 ml.) (Mean) } & \multirow[b]{2}{*}{$\begin{array}{l}\text { Pretreatment } \\
\text { Cholesterol }\end{array}$} & \multicolumn{2}{|c|}{ Patients } & \multicolumn{3}{|c|}{ Serum Cholesterol (mg./100 ml.) (Mean) } \\
\hline & No. & $\%$ & $\begin{array}{c}\text { Before } \\
\text { Treatment }\end{array}$ & $\begin{array}{l}\text { Treatment for } \\
3 \text { Months with } \\
3 \mathrm{~g} \text {./day Except } \\
\text { in Two Cases }\end{array}$ & $\underset{(\%)}{\text { Change }}$ & & No. & $\%$ & $\begin{array}{c}\text { Before } \\
\text { Treatment }\end{array}$ & $\begin{array}{l}\text { Treatment for } \\
3 \text { Months with } \\
3 \text { g./day Except } \\
\text { in Two Cases }\end{array}$ & $\begin{array}{l}\text { Change } \\
(\%)\end{array}$ \\
\hline $\begin{array}{l}\text { More than } 303 \mathrm{mg} . / \\
100 \mathrm{ml} . \\
\text { Less than } 303 \mathrm{mg} . / \\
100 \mathrm{ml} . .\end{array}$ & $\begin{array}{l}15 \\
18\end{array}$ & $\begin{array}{l}45 \\
55\end{array}$ & $\begin{array}{l}903 \\
771\end{array}$ & $\begin{array}{l}647 \\
561\end{array}$ & $\begin{array}{l}-23 \\
-27\end{array}$ & $\begin{array}{l}\text { More than } 303 \mathrm{mg} . / \\
100 \mathrm{ml} . \\
\text { Less than } 303 \mathrm{mg} . / \\
100 \mathrm{ml} .\end{array}$ & $\begin{array}{l}15 \\
18\end{array}$ & $\begin{array}{l}45 \\
55\end{array}$ & $\begin{array}{l}356 \\
260\end{array}$ & $\begin{array}{l}280 \\
230\end{array}$ & $\begin{array}{l}-21 \\
-12\end{array}$ \\
\hline
\end{tabular}


noticed by $15 \%$ of the patients during treatment. The flatulence caused such discomfort in one patient that treatment was discontinued. Anorexia was noted in only two subjects. One patient who had a previous history of duodenal ulcer suffered a slight recurrence of dyspepsia when N.A. treatment was started, but this was easily controlled by diet and antacids.

One patient complained of paraesthesiae, another developed a reactivation of an old tuberculous lesion, and a third developed renal tuberculosis during treatment. The association with N.A. therapy may have been quite accidental.

\section{Tests of Hepatic Function}

Tests of hepatic function were carried out on five of the patients who had been treated for 12 months or more. These tests were normal in all five.

\section{Uric Acid and Gout}

Nine subjects had repeated uric-acid examinations performed during the trial. Hyperuricaemia (uric acid $6 \mathrm{mg} . / 100 \mathrm{ml}$. or more) was present on at least one occasion in seven (78\%). Two persons developed gout during treatment with N.A. Neither of these patients had a history of gout. One responded to sulphinpyrazone ("anturan") and interruption of N.A. treatment was not necessary; the other failed to respond to standard uricosuric agents, but did respond to treatment with acetylsalicyclic acid.

\section{Discussion}

The results of this study, together with data reported elsewhere (Altschul et al., 1955; Achor et al., 1958; Achor and Berge, 1958 ; Berge et al., 1959 ; Parsons and Flinn, 1959), show that prolonged oral administration of large doses of N.A. produces a significant reduction in the level of serum cholesterol in most patients with hypercholesterolaemia. Also, it is clear that high total lipid levels can be reduced significantly in a majority of patients. This response of serum cholesterol and total lipids is usually sustained as long as the drug is taken. N.A. has no significant effect on fat tolerance or on heparin clearing.

Although treatment with N.A. is inexpensive and practicable to use the occurrence of side-effects continues to discourage and to limit the widespread clinical application of this substance. The initial period of flushing is seldom troublesome if the drug is taken during meals and if the nature of the symptom and its duration is explained to the patient. The drug should first be administered under medical supervision in hospital.

A number of our patients were obliged to stop the drug at various stages of treatment on account of furunculosis, gastrointestinal upset, etc., but with the adequate rapport between patient and physician most subjects can take N.A. in therapeutic doses for long periods. Every patient with persistent hypercholesterolaemia who fails to respond to dietetic and other measures should be offered the benefits of N.A. therapy.

It is not possible to say from this study whether treatment with N.A. alone or in combination with other drugs improves the prognosis of patients with atherosclerosis. However, it is possible that a significant reduction in abnormal bloodcholesterol levels may slow down or stop the process of atheroma formation.

\section{Summary}

Forty patients ( 32 men and 8 women) with initial fasting total-lipid and/or serum-cholesterol levels above 530 and 230 mg. $/ 100 \mathrm{ml}$. respectively were treated with nicotinic acid in large doses for varying periods.

Nicotinic acid lowered total-lipid and serum-cholesterol levels significantly. It did not cause a statistically significant change in the fasting, 2-hour, or 4-hour optical density nor in the 2-or 4-hour lipid rise following a standard fatty meal. Neither did it affect significantly the heparin clearing of lipaemic plasma.

Five persons who had an increased beta-lipoprotein band before treatment showed a satisfactory reversion to normal as soon as the serum cholesterol began to fall. The alpha-lipoprotein band showed a corresponding increase.

Side-effects of nicotinic-acid therapy are frequent but seldom necessitate withdrawal of the drug.

Two of us (A.H. and J.F.F.) are grateful to the Medical Research Council of Ireland for Research Fellowships. We also wish to acknowledge the generous supplies of the special $0.5 \mathrm{~g}$. tablets of nicotinic acid received from the British Drug Houses Ltd. in the earlier part of this study. We are grateful to Professor E. J. Conway, F.R.S., for hospitality in the Department of Biochemistry, University College, Dublin.

\section{REFERENCES}

Achor, R. W. P., and Berge, K. G. (1958). Med. Clin. N. Amer., 42, 871. 17, 497. Barker, N. W., and McKenzie, B. F. (1958). Circulation,

Altschul, R., Hoffer, A., and Stephen, J. D. (1955). Arch. Biochem., $54,558$.

Berge, K. G., Achor, R. W. P., Barker, N. W., and Power, M. H. (1959). Amer. Heart $\mathbf{f}$., 58, 849.

- Christensen, N. A., Mason, H. L., and Barker, N. W. (1961). Amer. F. Med., 31, 24.

Berkowitz, D., Croll, M. W., and Likoff, W. (1962). Amer. F. clin. Nutr., $10,107$.

Comesaña, F., Nava, A., Fishleder, B. L., and Sodi-Pallares, D. (1958). Amer. Heart $7 ., 55,476$.

FitzGerald, O., Heffernan, A., Fennelly, J. J., and McFarlane, R. (1963). Irish f. med. Sci., p. 201.

Mulcahy, R., Fennelly, J. J., and Heffernan, A. (1960). Lancet, $1,877$.

Galbraith, P. A., Perry, W. F., and Beamish, R. E. (1959). Lancet, 1. 222.

McFarlane, R. (1962). Irish f. med. Sci., p. 423.

O'Reilly, P. O., Demay, M., and Kotlowski, K. (1957). Arch. intern. Med., 100, 797.

Parsons, W. B. Jun., Achor, R. W. P. Berge, K. G. McKenzie, B. F., and Barker, N. W. (1956). Proc. Mayo Clin., 31, 377. and Flinn, J. H. (1959). Arch. intern. Med., 103, 783. 